\title{
Best Way to Protect Yourself in Public Wifi
}

\author{
Magdalene Peter, S.Fabiyola Kavitha, J.Pavithra
}

\begin{abstract}
Open Wi-Fi can be found in famous open spots like air terminals, cafés, shopping centers, eateries, and inns - and it enables you to get to the Internet for nothing. These "hotspots" are so across the board and regular that individuals as often as possible associate with them without reconsidering. In spite of the fact that it sounds innocuous to sign on and check your web based life record or peruse some news stories, perusing email, checking your ledger, or playing out any movement that requires a login is dangerous business on open Wi-Fi. The issue with open Wi-Fi is that there are a colossal number of dangers that accompany these systems. While entrepreneurs may accept they're giving a profitable support of their clients, odds are the security on these systems is careless or nonexistent. [1],[ 3],[5] Keywords : WIFI,association,Computer
\end{abstract}

\section{INTRODUCTION}

Getting to the web is ordinary and, as it were, sheltered on the off chance that you do it inside the kept limits of your home. It is secure, simple to associate with, and very uncongested except if the whole family is utilizing the Wi-Fi association for gushing applications. [2 ],[4],[6]

When you adventure outside however, it is a completely unique story. There are open Wi-Fi associations accessible like never before, enabling you to keep in contact with work or diversion from just anyplace you happen to be. However, getting associated with an open Wi-Fi association isn't that basic and protected for what it's worth with the in-home association. [7],[9] ,[11]

A Wi-Fi arrange accessible publically is intrinsically less sheltered than the private or individual one. It is on the grounds that you don't have a clue who built up it and who else is utilizing it. In a perfect world, you probably won't utilize the open system as you have a web association in your cell phone. Yet, there can be cases when there is no other useful choice available, and you need to utilize the open Wi-Fi organize.

\section{OBJECTIVES}

As you may know, Google Chrome let you know the webpage you are visiting utilizes a decoded HTTP association and not the scrambled HTTPS association by marking it 'Not Secure.' Keep a nearby beware of such alerts, particularly when you are utilizing open $\mathrm{Wi}-\mathrm{Fi}$ arranges as this can follow

Revised Manuscript Received on July 22, 2019.

Magdalene Peter, Department of MBA, Bharath Institute of Higher Education and Research, Tamilnadu, India. Email: magdalene.bsb@gmail.com

Fabiyola Kavitha, Department of MBA, Bharath Institute of Higher Education and Research, Tamilnadu, India. Email: fabiyolakavitha@gmail.com

J.Pavithra, department, Department of MBA, Bharath Institute of Higher Education and Research, Tamilnadu, India Email: pavithralect@yahoo.com information that movements among you and the site's server you are connecting to. With HTTP, it is very simple for them to watch what you are perusing and doing. [19],[21],[23]

\section{RESEARCH METHODOLOGY}

In the event that while utilizing open Wi-Fi you are asked for a lot of individual inquiries, similar to your telephone number, email, or more, you should abstain from giving the data. In the event that there is a direness to interface with such systems, it is insightful to adhere to [31],[33],[32]places that are dependable. Moreover, take a stab at utilizing an elective email ID instead of your essential one. Eateries and stores for the most part do this so as to get your own data and use it a while later for the furthertrade-off. [13], [15] ,[17]

What's more, attempt to pursue less unique open Wi-Fi organizes as could be allowed. For instance, on the off chance that it is conceivable to get associated with a system through an administration you are as of now utilizing, at that point it is ideal that you use it as opposed to marking through another organization. [8],[10],[12]

\section{RESULT AND DISCUSSION}

It is basic to check the joined terms and conditions before you associate with an open $\mathrm{Wi}-\mathrm{Fi}$ association. You probably won't almost certainly see every single word, yet should most likely recognize the significant warnings, particularly around the kind of information they are gathering from the session and what they are doing with the gathered information. [25],[27],[29]

In the event that you find any approach to be impervious, run a brisk web search to think about issues or issues that different clients may have encountered. Don't simply aimlessly tap on sites or stuff that spring up on your cell phone screens. What's more, on the off chance that they request that you introduce any program expansion or additional product, at that point step back in a flash.. [14], [ 16], [18]

\section{V.CONCLUSION}

When utilizing an open Wi-Fi organize, you are encompassed by outsiders. You would need to remove the highlights that permit frictionless document sharing on the gadgets. On a PC, this infers visiting the Network and Sharing focus, at that point change the propelled sharing settings, and turn off record 
and printer sharing. [20],[22], [24]

For cell phones and Macs, it is going to framework inclinations, at that point sharing, and unselects everything. The following stage is to make a beeline for the discoverer, click on Airdrop and select 'empower me to be found by nobody.' Doing this will guarantee that nobody adjacent can catch your records or send you stuff that you don't need[26],[28],[30]

\section{REFERENCES}

1. G BharthVajan R., Ramachandran S.,Psychographic dimensions of training,2016,International Journal of Pharmacy and Technology,V-8,I-4,P-23727-23729

2. Balakrishnan P., Bharthvajan R.,A study on human resource planning in hospitals in Chennai City,2014,International Journal of Applied Engineering Research,V-9,I-22,P-7503-7507

3. Priyadarsini P., Bharthvajan R.,Role of emotional intelligence training programme in reducing the stress of the nurses,2014,International Journal of Applied Engineering Research,V-9,I-22,P-7411-7421

4. Kerinab Beenu G., Bharthvajan R.,Empirical analysis on the cosmetic buying behavior of young women in South India,2014,International Journal of Applied Engineering Research,V-9,I-22,P-7361-7366

5. Balakrishnan P., Bharthvajan R.,Whistling in the wind,2014,International Journal of Applied Engineering Research,V-9,I-22,P-7586-7593

6. Krishnan B., Peter M.,Health hazards of Indian Bpo employee-an alarming issue,2014,International Journal of Applied Engineering Research,V-9,I-22,P-7336-7341

7. Kerinab Beenu G.H., Peter M.,Role of insurance in economic development,2014,International Journal of Applied Engineering Research,V-9,I-22,P-7532-7539

8. Balakrishnan P., Peter M., Priyadarsini P.,Efficiency of safety measures for wellbeing of employees in manufacturing industry,2014,International Journal of Applied Engineering Research,V-9,I-22,P-7376-7382

9. Anbarasi M., Praveen Kumar S.,Online sales promotions of herbal products and its effectiveness towards tanisha.com,2019,Indian Journal of Public Health Research and Development,V-10,I-1,P-195-200

10. Anbarasi M., Praveen Kumar S.,Various online marketing and promotions strategies to improve the validation towards the organic products in the pharmaceutical sectors,2019,Indian Journal of Public Health Research and Development,V-10,I-1,P-263-269

11. Loganathan R., Praveen Kumar S.,Grievance handling a key factor for solving issues of employees in an organization,2014,International Journal of Applied Engineering Research,V-9,I-22,P-7483-7491

12. Loganathan R., Praveen Kumar S.,Study on preference of private label brands in super and Hypermarkets,2014,International Journal of Applied Engineering Research,V-9,I-22,P-7327-7335

13. Smitha M., Praveen Kumar S.,Understanding stress and its managementamong the nurses in Chennai city,2014,International Journal of Applied Engineering Research,V-9,I-22,P-7560-7565

14. Kerinab Beenu G.H., Praveen Kumar S.,A study on the investment behavior of Chennai investors in mutual fund schemes,2014,International Journal of Applied Engineering Research,V-9,I-22,P-7520-7525

15. Loganathan R., Praveen Kumar S.,Retention strategies key for organizational productivity,2014,International Journal of Applied Engineering Research,V-9,I-22,P-7443-7447

16. Pavithra J., Ganesan M., Brindha G.,State wise analysis of microfinance sector in India,2016, International Journal of Pharmacy and Technology,V-8,I-4,P-23417-23432

17. Pavithra J., Ganesan M.,A comparative study on microfinance in India and abroad,2016,International Journal of Applied Business and Economic Research,V-14,I-8,P-5471-5476

18. Pavithra J., Ganesan M.,A study on awareness and impact of micro-financial schemes,2016,International Journal of Applied Business and Economic Research,V-14,I-8,P-5449-5460

19. Senthilmurugan P., Pavithra J.,Consumer preference towards organised retailing with reference to Big Bazaar,2014,International Journal of Applied Engineering Research,V-9,I-22,P-7469-7475

20. Senthilmurugan P., Pavithra J.,Implication of social media marketing in growing healthcare industry,2014,International Journal of Applied Engineering Research,V-9,I-22,P-7448-7456

21. Loganathan R., Pavithra J.,Consumer perception towards private label brand over other brands in super markets and hypermarkets,2014,International Journal of Applied Engineering Research,V-9,I-22,P-7355-7360
22. Kerinab Beenu G., Pavithra J.,Tradeâ€"off between liquidity and profitability in logistics industry,2014,International Journal of Applied Engineering Research,V-9,I-22,P-7398-7401


perception towards utility cars in Chennai city,2014,International Journal of Applied Engineering Research,V-9,I-22,P-7526-7531

24. Pavithra J., Dilli Babu P., Ambuli T.V.,A study on budgetary control at Maruti Service Masters, Chennai,2014,International Journal of Applied Business and Economic Research,V-12,I-2,P-151-161

25. Pavithra J., Dilli Babu P., Ambuli T.V.,A study on customer satisfaction of retro Garments Pvt Ltd, Chennai,2014,International Journal of Applied Business and Economic Research,V-12,I-2,P-381-391

26. Kerinab Beenu G.H., Pavithra J., Senthilmurugan P.,A study on the influence of promotional activities for TATA ARIA among consumers in Chennai,2014,International Journal of Applied Engineering Research,V-9,I-22,P-7572-7578

27. Vijayaragavan S.P.,An investigative expert that's general FBG sensors,International Journal of Mechanical Engineering and Technology,V-8,I-8,PP-1500-1505,Y-2017

28. Vijayaragavan S.P.,Equalization routing protocol for Wi-Fi sensor strategy,International Journal of Mechanical Engineering and Technology,V-8,I-8,PP-1662-1666,Y-2017

29. Karthik B., Kiran Kumar T.V.U., Vijayaragavan P., Bharath Kumaran E.,Design of a digital PLL using 0.35 ̂ิ1/4m CMOS technology,Middle East Journal of Scientific Research,V-18,I-12,PP-1803-1806,Y-2013

30. Kanniga E., Selvaramarathnam K., Sundararajan M.,Kandigital bike operating system,Middle - East Journal of Scientific Research,V

31. Jasmin M., Vigneshwaran T., Beulah Hemalatha S.,Design of power aware on chip embedded memory based FSM encoding in FPGA,International Journal of Applied Engineering Research,V-10,I-2,PP-4487-4496,Y-2015

32. Jasmin M.,Optimization techniques for low power VLSI circuits,Middle East Journal of Scientific Research,V-20,I-9,PP-1082-1087,Y-2014

33. Jasmin M., Vigneswaran T.,Fuzzy controller for error control of on - Chip communication,2017 International Conference on Algorithms, Methodology, Models and Applications in Emerging Technologies, ICAMMAET 2017,V-2017-January,I-,PP-1-5,Y-2017

\section{AUTHORS PROFILE}

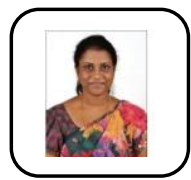

Magdalene Peter Assistant Professor, Department of MBA, Bharath Institute of Higher Education and Research, Tamilnadu, India



Fabiyola Kavitha Associate Professor, Department of MBA, Bharath Institute of Higher Education and Research, Tamilnadu, India

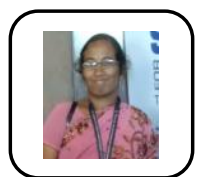

J.Pavithra Assistant Professor ,Department of MBA, Bharath Institute of Higher Education and Research, Tamilnadu, India 